\title{
Hubungan Faktor Air dan Sanitasi dengan Kejadian Stunting pada Balita di Indonesia
}

\author{
Annita Olo ${ }^{\varpi_{1}}$, Henny Suzana Mediani2 ${ }^{2}$ Windy Rakhmawati ${ }^{3}$ \\ Keperawatan, Universitas Padjadjaran \\ DOI: $\underline{10.31004 / \text { obsesi.v5i2.521 }}$
}

\begin{abstract}
Stunting di Indonesia menjadi masalah kesehatan masyarakat secara nasional dalam kategori tinggi, mencapai 30,8\% ditahun 2018. Salah satu penyebab stunting dikaitkan dengan faktor air dan sanitasi. Review artikel ini bertujuan untuk menganalisis hubungan faktor air, sanitasi dengan kejadian stunting pada balita di Indonesia. Metode penelitian menggunakan systematic review, dengan pencarian literatur menggunakan beberapa electronic database. Kriteria inklusi artikel: menjelaskan faktor air, sanitasi dengan kejadian stunting pada balita di Indonesia, desain studi observasional, tahun publikasi 2015-2020. Hasil studi 21 artikel menunjukkan bahwa faktor air (sumber air minum tidak layak, pengolahan air minum), faktor sanitasi (penggunaan fasilitas toilet, perilaku open defecation, pembuangan tinja balita tidak pada jamban) berhubungan dengan kejadian stunting pada balita di Indonesia. Kesimpulan studi ini mengungkapkan bahwa air dan sanitasi merupakan faktor yang berhubungan dengan stunting pada balita di Indonesia. Upaya promosi kesehatan dan kerja sama lintas sektoral dalam intervensi gizi sensitif perlu ditingkatkan untuk mencegah stunting di Indonesia.
\end{abstract}

Kata Kunci: air; balita, indonesia; sanitasi; stunting

\begin{abstract}
Stunting in Indonesia is a public health problem nationally in the high category, reaching $30.8 \%$ in 2018. One of causes of stunting related to water and sanitation factors. This review article aims to analyze relationship water and sanitation factors and incidence of stunting in children under five in Indonesia. The research method uses systematic review, with literature searches using several electronic databases. Article inclusion criteria: explaining the water factor, sanitation with the incidence of stunting in children under five in Indonesia, observational study design, publication year 2015-2020. The results study of 21 articles indicate that water factors (unimproved drinking water sources, drinking water treatment), sanitation factors (use toilet facilities, open defecation behavior, disposal of underfives' feces not in latrines) are associated with the incidence of stunting in children under five in Indonesia. The conclusion this study reveals that water and sanitation are factors that are associated with stunting in children under five in Indonesia. Health promotion efforts and intersectoral cooperation in sensitive nutrition interventions need to be increased to prevent stunting in Indonesia.
\end{abstract}

Keywords: children under five; indonesia; sanitation; stunting; water.

Copyright (c) 2020 Annita Olo, Henny Suzana Mediani, Windy Rakhmawati

$\triangle$ Corresponding author :

Email Address : annitaolo1977@gmail.com (Bandung, Jawa Barat, Indonesia)

Received tanggal bulan tahun, Accepted 28 September 2020, Published 29 September 2020 


\section{PENDAHULUAN}

Stunting merupakan salah satu masalah gizi pada balita yang menjadi perhatian dunia dalam beberapa tahun terakhir, terutama di negara-negara berpenghasilan rendah dan menengah termasuk Indonesia (Bukusuba et al., 2017; Hossain et al., 2017; Kemenkes RI, 2018). Stunting menunjukkan terjadi gangguan pertumbuhan linear (panjang badan/tinggi badan menurut usia) berada dibawah -2 Standar Deviasi (<-2SD) sesuai standar median World Health Organization (WHO), terjadi akibat kekurangan gizi kronis dan infeksi berulang selama 1000 hari pertama kehidupan (HPK) (Vilcins et al., 2018; Mbuya \& Humphrey, 2016).

Secara global terdapat 155 juta anak usia dibawa lima tahun (balita) mengalami stunting (Vonaesch et al, 2018; Batiro et al, 2017). Data WHO (2018), melaporkan bahwa Indonesia merupakan salah satu negara penyumbang angka kejadian stunting tertinggi urutan ketiga di Asia Tenggara mencapai 36,4\% dari tahun 2005-2017 (Kemenkes RI, 2018). Prevalensi balita stunting di Indonesia berdasarkan laporan riset kesehatan dasar (Riskesdas), mengalami peningkatan dari tahun 2016 hingga 2018 yaitu 27,5\% di tahun 2016, 29,6\% di tahun 2017 dan meningkat 30,8\% di tahun 2018 (Riskesdas, 2018; Kemenkes RI, 2018). Stunting di Indonesia menjadi masalah kesehatan masyarakat secara nasional yang perlu mendapat perhatian secara serius, karena tergolong dalam kategori tinggi sesuai standar WHO mencapai 30-39\%. Hasil Riskesdas (2018), menunjukkan bahwa dari 34 provinsi di Indonesia memiliki prevalensi kejadian stunting yang berbeda-beda. Terdapat dua provinsi dengan angka kejadian sangat tinggi melebihi $40 \%$ sesuai kriteria WHO yaitu: Nusa Tenggara Timur sebanyak 42,7\% dan Sulawesi Barat sebanyak 41,6\%, sedangkan 17 provinsi sebagai penyumbang angka kejadian stunting mencapai 30-39\% dengan kategori tinggi.

Permasalahan stunting yang terjadi pada masa kanak-kanak berdampak pada kesakitan, kematian, gangguan pertumbuhan fisik, gangguan perkembangan mental, kognitif dan gangguan perkembangan motorik. Gangguan yang terjadi cenderung bersifat ireversibel dan berpengaruh terhadap perkembangan selanjutnya yang dapat meningkatkan resiko penyakit degeneratif saat dewasa (de Onis \& Branca, 2016; WHO, 2018; Kemenkes RI, 2018; Vonaesch et al., 2018). Dampak lain yang terjadi akibat stunting dimana anak memiliki kecerdasan kurang yang berpengaruh pada prestasi belajar tidak optimal dan produktivitas menurun. Jika hal ini terus berlanjut maka akan menghambat perkembangan produktivitas suatu bangsa di masa yang akan datang ( Hossain et al., 2017; Kemenkes RI, 2018; Trihono et al, 2015).

Penyebab stunting terdiri dari banyak faktor yang saling berpengaruh satu sama lain dan penyebabnya berbeda disetiap daerah (Kwami et al, 2019; Saputri \& Tumangger, 2019). Penyebab stunting secara langsung meliputi asupan nutrisi tidak adekuat dan penyakit infeksi. Secara tidak langsung stunting dapat disebabkan oleh faktor ketahanan pangan keluarga, pola asuh, pelayanan kesehatan dan kesehatan lingkungan yang tidak memadai mencakup air dan sanitasi. Penyebab dasar terjadinya stunting dihubungkan dengan pendidikan, kemiskinan, sosial budaya, kebijakan pemerintah dan politik (UNICEF, 2013 dalam Trihono et al, 2015; Kemenkes RI, 2018; Fenske et al, 2013 ; WHO, 2014).

Faktor sanitasi lingkungan yang buruk meliputi akses air bersih yang tidak memadai, penggunaan fasilitas jamban yang tidak sehat dan perilaku higiene mencuci tangan yang buruk berkontribusi terhadap peningkatan penyakit infeksi seperti diare, Environmental Enteric Dysfunction (EED), cacingan. Kondisi tersebut dapat menyebabkan gangguan pertumbuhan linear serta dapat meningkatkan kematian pada balita (Kwami et al., 2019; Headey \& Palloni, 2019; Cumming \& Cairncross, 2016; BAPPENAS \& UNICEF,2017).

Penelitian tentang permasalahan stunting dengan penyebab yang kompleks dilakukan diberbagai negara terutama dinegara dengan penghasilan rendah dan menengah. Penelitian yang dilakukan tidak hanya berfokus pada masalah gizi dan penyakit infeksi sebagai penyebab stunting, melainkan faktor-faktor pendukung lainnya seperti kecukupan gizi orang 
tua, status sosial ekonomi keluarga. Salah satu faktor penyebab yang erat kaitan dengan stunting adalah faktor air, sanitasi dan higiene (Aguayo \& Menon, 2016; Hossain et al, 2017; Chakravarty et al, 2017; Rabaoarisoa et al, 2017). Penelitian tentang determinan faktor air (Water), sanitasi (Sanitation) dengan kejadian stunting pada balita belum banyak diteliti di Indonesia dibandingkan dengan negara berkembang lainnya. Tujuan review artikel ini untuk menganalisis hubungan faktor air, sanitasi dengan kejadian stunting pada balita di Indonesia.

\section{METODOLOGI}

Penelitian ini menggunakan rancangan systematic review untuk mengidentifikasi, mengevaluasi, dan merangkum semua temuan berkualitas dan relevan yang berkaitan dengan hubungan faktor air, sanitasi dengan kejadian stunting pada balita di Indonesia. Systematic review ini dimulai dengan review pertanyaan: Apakah Faktor Air Dan Sanitasi berhubungan dengan Kejadian Stunting Pada Balita Di Indonesia? faktor air mencakup Artikel- artikel yang dipilih apabila 1) population dalam studi balita di Indonesia. 2) Exposure of interest menjelaskan faktor air dan sanitasi 3) Outcome Kejadian stunting di Indonesia 4) Studi observasional (Cohort study, Case Control, Cross Sectional) 5) Tahun publikasi 20152020 6) Berbahasa inggris dan Indonesia 7) full text.

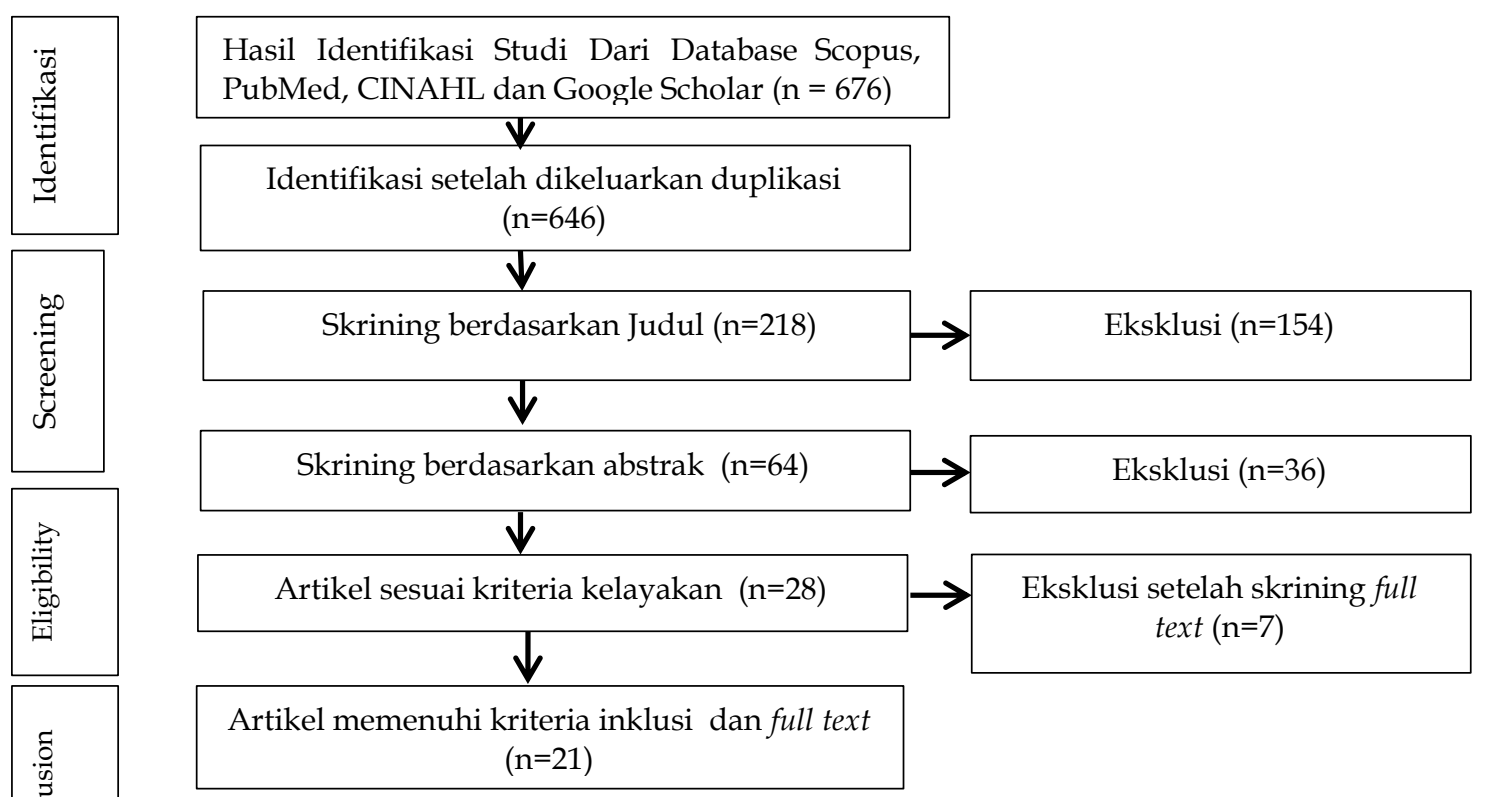

Gambar 1 Diagram Flow Proses Pencarian Artikel

Pencarian literatur hasil publikasi ilmiah dalam systematic review ini menggunakan beberapa electronic database yaitu CINAHL, Pubmed, SCOPUS dan google scholar dengan kata kunci yang digunakan adalah Water "AND" Sanitation "AND" Child "AND" Stunting "AND" Indonesia. Sedangkan pencarian melalui google scholar dengan kata kunci Air, Sanitasi, Stunting, Balita, Indonesia. Limit waktu yang ditetapkan dalam judul artikel tahun 2015-2020 dengan format full text dalam bentuk pdf. Data faktor air difokuskan pada sumber air, kuantitas dan kualitas air serta pengolahan air. Sedangkan faktor sanitasi mencakup penggunaan fasilitas toilet, kepemilikan toilet, perilaku open defekasi dan pembuangan tinja balita pada jamban. Proses pencarian hingga penyeleksian sejumlah artikel menggunakan preferred reporting items for systematic reviews and meta analysis (PRISMA). Proses seleksi terlihat pada gambar 1 . 
Penilaian kualitas studi terhadap sejumlah artikel yang dipilih berdasarkan The JBI critical appraisal tool untuk studi observasional (Cohort study, Case Control, Cross Sectional). Studi yang beresiko tinggi bias dikeluarkan. Berdasarkan hasil penilaian kualitas studi tinggi, dilakukan ekstraksi data.

Sintesis data dalam systematic review ini menggunakan sintesis naratif dengan memberikan ringkasan informasi yang berhubungan dengan faktor air dan sanitasi dengan kejadian stunting pada balita di Indonesia. Hubungan positif faktor air dan sanitasi dengan kejadian stunting dari setiap artikel diperoleh apabila hasil uji statistik signifikan, nilai odd ratio (OR) lebih dari satu dengan nilai interval kepercayaan $95 \%$.

\section{HASIL DAN PEMBAHASAN}

Berdasarkan hasil skrining artikel dan penetapan kriteria kelayakan diperoleh 21 artikel Original Research yang memenuhi kriteria inklusi untuk dilakukan review. Semua artikel yang direview menggunakan studi observasional (Cohort study, Case Control, Cross Sectional). Hasil studi tersebut dapat terlihat dalam tabel ekstraksi dibawah ini :

Tabel 1. Ekstraksi Data

\begin{tabular}{|c|c|c|c|c|c|c|}
\hline No & $\begin{array}{l}\text { Penulis / } \\
\text { Tahun }\end{array}$ & Judul Penelitian & $\begin{array}{l}\text { Variabel } \\
\text { Penelitian } \\
\text { (VI dan VD) }\end{array}$ & $\begin{array}{l}\text { Desain } \\
\text { Penelitian }\end{array}$ & Sampel & Hasil \\
\hline 1 & $\begin{array}{l}\text { Ahmadi et } \\
\text { al., } 2020\end{array}$ & $\begin{array}{l}\text { Association Between } \\
\text { Toilet Availability } \\
\text { and HandWashing } \\
\text { Habits and the } \\
\text { Incidence of Stunting } \\
\text { in Young Children in } \\
\text { Tanjung Pinang City, } \\
\text { Indonesia }\end{array}$ & $\begin{array}{l}\text { VI: } \\
\text { - Ketersediaan } \\
\text { fasilitas toilet } \\
\text { VD: Stunting }\end{array}$ & $\begin{array}{l}\text { Cross- } \\
\text { Sectional }\end{array}$ & $\begin{array}{l}82 \text { anak } \\
\text { usia } 24- \\
59 \\
\text { bulan }\end{array}$ & $\begin{array}{l}\text { Ketersediaan fasilitas } \\
\text { toilet tidak } \\
\text { memenuhi syarat } \\
(\mathrm{P}=0,016) \\
\text { berhubungan dengan } \\
\text { kejadian stunting } \\
\text { pada anak usia } 24-59 \\
\text { bulan }\end{array}$ \\
\hline 2 & $\begin{array}{l}\text { Badriyah, L., } \\
\& \text { Syafiq, } \\
2017\end{array}$ & $\begin{array}{l}\text { The Association } \\
\text { Between Sanitation, } \\
\text { Hygiene, and } \\
\text { Stunting in Children } \\
\text { Under Two-Years } \\
\text { (An Analysis of } \\
\text { Indonesia's Basic } \\
\text { Health Research, } \\
\text { 2013) }\end{array}$ & $\begin{array}{l}\text { VI: } \\
\text { - Sumber air } \\
\text { - Kualitas air } \\
\text { - Jarak sumber } \\
\text { air } \\
\text { pembuangan } \\
\text { - Fasilitas toilet } \\
\text { - Open } \\
\text { defecation } \\
\text { VD: Stunting }\end{array}$ & $\begin{array}{l}\text { Cross- } \\
\text { Sectional }\end{array}$ & $\begin{array}{l}9.688 \\
\text { anak di } \\
\text { bawah } \\
\text { usia } \\
\text { dua } \\
\text { tahun. }\end{array}$ & $\begin{array}{l}\text { Sumber air } \\
\text { unimproved } \\
(\mathrm{OR}=1,18) \text {, fasilitas } \\
\text { toilet tidak } \\
\text { memenuhi syarat } \\
(\mathrm{OR}=1,33) \text {, perilaku } \\
\text { open defecation } \\
(\mathrm{OR}=1,39) \\
\text { berhubungan dengan } \\
\text { peningkatan kejadian } \\
\text { stunting pada anak } \\
\text { usia dibawah dua } \\
\text { tahun di } 33 \text { Provinsi } \\
\text { di Indonesia }\end{array}$ \\
\hline 3 & $\begin{array}{l}\text { Choirunnisa } \\
\text { et al., } 2020\end{array}$ & $\begin{array}{l}\text { Analysis Of Factors } \\
\text { Related To Stunting } \\
\text { In Toddlers Aged 25- } \\
59 \text { Months In } \\
\text { Puspasari Village, } \\
\text { Puspahiyang, } \\
\text { Tasikmalaya } 2019\end{array}$ & $\begin{array}{l}\text { VI: } \\
\text { - Sanitasi } \\
\text { lingkungan } \\
\text { VD: Stunting }\end{array}$ & $\begin{array}{l}\text { Cross- } \\
\text { Sectional }\end{array}$ & $\begin{array}{l}74 \text { anak } \\
\text { usia } 25- \\
59 \\
\text { bulan }\end{array}$ & $\begin{array}{l}\text { Sanitasi lingkungan } \\
(\mathrm{p}=0.004 ; \mathrm{OR}=6,261) \\
\text { berhubungan dengan } \\
\text { peningkatan kejadian } \\
\text { stunting pada anak } \\
\text { usia 25-59 bulan di } \\
\text { desa Puspasari, } \\
\text { Puspahiyang, } \\
\text { Tasikmalaya. }\end{array}$ \\
\hline 4 & $\begin{array}{l}\text { Dwipayanti } \\
\text { et al., } 2020\end{array}$ & $\begin{array}{l}\text { Potential } \\
\text { Association of } \\
\text { Sanitation Factors }\end{array}$ & $\begin{array}{l}\text { VI: } \\
\text { - Pilar 1: akses } \\
\text { sanitasi yang }\end{array}$ & $\begin{array}{l}\text { Case- } \\
\text { Control }\end{array}$ & $\begin{array}{l}202 \\
\text { anak } \\
\text { usia 2-5 }\end{array}$ & $\begin{array}{l}\text { Pilar } 1 \text { STBM akses } \\
\text { sanitasi mencakup: } \\
\text { akses toilet di rumah }\end{array}$ \\
\hline
\end{tabular}




\begin{tabular}{|c|c|c|c|c|c|c|}
\hline No & $\begin{array}{l}\text { Penulis / } \\
\text { Tahun }\end{array}$ & Judul Penelitian & $\begin{array}{l}\text { Variabel } \\
\text { Penelitian } \\
\text { (VI dan VD) }\end{array}$ & $\begin{array}{l}\text { Desain } \\
\text { Penelitian }\end{array}$ & Sampel & Hasil \\
\hline & & $\begin{array}{l}\text { on Stunting } \\
\text { Incidences Among } \\
\text { Children Under } \\
\text { Age } 5 \text { in Bali } \\
\text { Province, Indonesia }\end{array}$ & $\begin{array}{l}\text { layak (akses } \\
\text { toilet di rumah, } \\
\text { kepemilikan } \\
\text { jamban sendiri, } \\
\text { penggunaan } \\
\text { jamban sharing, } \\
\text { penggunaan } \\
\text { toilet oleh bayi, } \\
\text { pembuangan } \\
\text { tinja balita } \\
\text { - Pilar 3: sumber } \\
\text { air minum yang } \\
\text { aman, akses } \\
\text { suplai air } \\
\text { dirumah, } \\
\text { kuantitas air, } \\
\text { penampungan } \\
\text { air minum } \\
\text { VD: Stunting }\end{array}$ & & $\begin{array}{l}\text { tahun } \\
\text { dibagi: } \\
101 \\
\text { kasus } \\
\text { dan } 101 \\
\text { kontrol }\end{array}$ & $\begin{array}{l}(\mathrm{p}=0,024) \text {, } \\
\text { kepemilikan toilet }(\mathrm{p}= \\
0,009) \text {, penggunaan } \\
\text { toilet oleh bayi }(\mathrm{p}= \\
0,002) \text {, pembuangan } \\
\text { tinja bayi tidak pada } \\
\text { jamban ( } \mathrm{p}=0,002) \text {, } \\
\text { memiliki hubungan } \\
\text { signifikan dengan } \\
\text { kejadian stunting. }\end{array}$ \\
\hline 5 & $\begin{array}{l}\text { Hasanah \& } \\
\text { Susanti., } \\
2018\end{array}$ & $\begin{array}{l}\text { Does water and } \\
\text { sanitation effects on } \\
\text { children's physical } \\
\text { development? } \\
\text { Evidence from } \\
\text { Indonesia Family } \\
\text { life Survey (IFLS) } \\
2014\end{array}$ & $\begin{array}{l}\text { VI: } \\
\text { - Air } \\
\text { - Sanitasi } \\
\text { VD: Stunting }\end{array}$ & $\begin{array}{l}\text { Cross- } \\
\text { Sectional }\end{array}$ & $\begin{array}{l}2835 \\
\text { anak } \\
\text { usia } 0-5 \\
\text { tahun }\end{array}$ & $\begin{array}{l}\text { Sanitasi yang layak } \\
\text { mengurangi kejadian } \\
\text { stunting } 0,645 \text { kali, } \\
\text { mengkonsumsi air } \\
\text { dari sumber } \\
\text { improved } 0,874 \text { kali } \\
\text { mengurangi kejadian } \\
\text { stunting pada anak } \\
\text { balita di } 13 \text { Provinsi } \\
\text { di Indonesia. }\end{array}$ \\
\hline 6 & $\begin{array}{l}\text { Irianti S, et } \\
\text { al., } 2019\end{array}$ & $\begin{array}{l}\text { The Role Of Drinking } \\
\text { Water Source, } \\
\text { Sanitation, And Solid } \\
\text { Waste Management } \\
\text { In Reducing } \\
\text { Childhood Stunting } \\
\text { In Indonesia }\end{array}$ & $\begin{array}{l}\text { VI: } \\
\text { - Sumber air } \\
\text { minum } \\
\text { - Fasilitas sanitasi } \\
\text { VD: Stunting }\end{array}$ & $\begin{array}{l}\text { Cross- } \\
\text { Sectional }\end{array}$ & $\begin{array}{l}2.571 \\
\text { anak } \\
\text { balita }\end{array}$ & $\begin{array}{l}\text { Sumber air minum } \\
\text { unimproved } \\
(\mathrm{OR}=1,21) \\
\text { meningkatkan } \\
\text { kejadian stunting } \\
\text { pada balita yang } \\
\text { tinggal di pedesaan } \\
\text { di } 13 \text { provinsi } \\
\text { Indonesia. }\end{array}$ \\
\hline 7 & $\begin{array}{l}\text { Fikru \& } \\
\text { Doorslaer, } \\
2019\end{array}$ & $\begin{array}{l}\text { Explaining the fall of } \\
\text { socioeconomic } \\
\text { inequality in } \\
\text { childhood stunting in } \\
\text { Indonesia }\end{array}$ & $\begin{array}{l}\text { VI: } \\
\text { - Air minum } \\
\text { yang aman } \\
\text { - Sanitasi } \\
\text { VD: Stunting }\end{array}$ & $\begin{array}{l}\text { Cross- } \\
\text { Sectional }\end{array}$ & $\begin{array}{l}8970 \\
\text { anak } \\
\text { balita }\end{array}$ & $\begin{array}{l}\text { Air minum yang } \\
\text { aman }(p=-0,011) \text {, } \\
\text { sanitasi yang layak } \\
(p=-0,035), \\
\text { berkontribusi positif } \\
\text { terhadap } \\
\text { pengurangan } \\
\text { kejadian stunting dan } \\
\text { stunting berat pada } \\
\text { anak balita di } 13 \\
\text { Provinsi Indonesia } \\
\text { pada tahun 2007- } \\
2014 .\end{array}$ \\
\hline 8 & $\begin{array}{l}\text { Otsuka et al., } \\
2019\end{array}$ & $\begin{array}{l}\text { Risk Factors for } \\
\text { Undernutrition and } \\
\text { Diarrhea Prevalence } \\
\text { in an Urban Slum in }\end{array}$ & $\begin{array}{l}\text { VI: } \\
\text { - Sumber air } \\
\text { minum }\end{array}$ & $\begin{array}{l}\text { Cross- } \\
\text { Sectional }\end{array}$ & $\begin{array}{l}228 \\
\text { anak } \\
\text { balita } \\
\text { dengan }\end{array}$ & $\begin{array}{l}\text { Mengkonsumsi air } \\
\text { minum yang } \\
\text { bersumber dari air } \\
\text { ledeng ( } p=0,027 ;\end{array}$ \\
\hline
\end{tabular}




\begin{tabular}{|c|c|c|c|c|c|c|}
\hline No & $\begin{array}{l}\text { Penulis / } \\
\text { Tahun }\end{array}$ & Judul Penelitian & $\begin{array}{l}\text { Variabel } \\
\text { Penelitian } \\
\text { (VI dan VD) }\end{array}$ & $\begin{array}{l}\text { Desain } \\
\text { Penelitian }\end{array}$ & Sampel & Hasil \\
\hline & & $\begin{array}{l}\text { Indonesia: Focus on } \\
\text { Water, Sanitation, } \\
\text { and Hygiene. }\end{array}$ & $\begin{array}{l}\text { - Penyimpanan } \\
\text { air minum } \\
\text { - Tipe jamban } \\
\text { - Penampungan } \\
\text { akhir toilet } \\
\text { - Kebiasaan } \\
\text { praktik cuci } \\
\text { tangan } \\
\text { VD: Stunting }\end{array}$ & & $\begin{array}{l}\text { pengas } \\
\text { uhnya }\end{array}$ & $\begin{array}{l}\text { OR=2,26) } \\
\text { dibandingkan dengan } \\
\text { rumah tangga yang } \\
\text { menggunakan air } \\
\text { tangki dan sumur. } \\
\text { Penggunaaan } \\
\text { penampungan akhir } \\
\text { toilet yang tidak } \\
\text { menggunakan septi } \\
\text { tank (p=0,127; OR= } \\
2,06 \text { kali) } \\
\text { berhubungan dengan } \\
\text { peningkatan kejadian } \\
\text { stunting pada anak- } \\
\text { anak yang tinggal } \\
\text { dilokasi Urban } \\
\text { Bandung. }\end{array}$ \\
\hline 9 & $\begin{array}{l}\text { Rahayu et } \\
\text { al., } 2017\end{array}$ & $\begin{array}{l}\text { Child Care Practice } \\
\text { As A Risk Factor Of } \\
\text { Changes In } \\
\text { Nutritional Status } \\
\text { From Normal To } \\
\text { Stunting In } \\
\text { Children Under } \\
\text { Five }\end{array}$ & $\begin{array}{l}\text { VI : Sanitasi } \\
\quad \text { lingkungan } \\
\text { VD: Stunting }\end{array}$ & Cohort & $\begin{array}{l}571 \\
\text { anak } \\
\text { balita }\end{array}$ & $\begin{array}{l}\text { Sanitasi lingkungan } \\
\text { tidak layak ( } \mathrm{p}=0,007 ; \\
\text { OR=1,64) } \\
\text { berhubungan dengan } \\
\text { peningkatan kejadian } \\
\text { stunting pada balita } \\
\text { yang tinggal di } \\
\text { pedesaan kabupaten } \\
\text { tanggerang Provinsi } \\
\text { Banten. }\end{array}$ \\
\hline 10 & $\begin{array}{l}\text { Rahayu et } \\
\text { al., } 2018\end{array}$ & $\begin{array}{l}\text { The Biopsychosocial } \\
\text { Determinants of } \\
\text { Stunting and } \\
\text { Wasting in Children } \\
\text { Aged 12-48 Months }\end{array}$ & $\begin{array}{l}\text { VI: } \\
\text { - Sumber air } \\
\text { minum } \\
\text { - Fasilitas sanitasi } \\
\text { VD: Stunting, } \\
\text { Wasting }\end{array}$ & $\begin{array}{l}\text { Case } \\
\text { Control }\end{array}$ & $\begin{array}{l}150 \\
\text { anak } \\
\text { balita } \\
\text { usia } 12- \\
48 \\
\text { bulan }\end{array}$ & $\begin{array}{l}\text { Penggunaan fasilitas } \\
\text { sanitasi tidak layak } \\
(p=0,002 ; \text { OR }=8,51) \text {, } \\
\text { sumber air minum } \\
(p=0,259 ; \text { OR }=1,67) \\
\text { berhubungan dengan } \\
\text { peningkatan kejadian } \\
\text { stunting pada balita } \\
\text { di Kabupaten Tulang } \\
\text { Bawang Barat. }\end{array}$ \\
\hline 11 & Siswati, 2018 & $\begin{array}{l}\text { Risk Factors For } \\
\text { Stunting And Severe } \\
\text { Stunting Among } \\
\text { Under Five Years } \\
\text { Children In Rural } \\
\text { Areas In Indonesia. }\end{array}$ & $\begin{array}{l}\text { VI: } \\
\text { - Air, sanitasi dan } \\
\text { higiene } \\
\text { (WASH) } \\
\text { VD: Stunting dan } \\
\quad \text { stunting } \\
\quad \text { berat }\end{array}$ & $\begin{array}{l}\text { Cross- } \\
\text { Sectional }\end{array}$ & $\begin{array}{l}18.225 \\
\text { anak } \\
\text { usia } 0 \text { - } \\
59 \\
\text { bulan }\end{array}$ & $\begin{array}{l}\text { Water, sanitation, } \\
\text { Hygiene (WASH) } \\
\text { yang buruk }(\mathrm{p}=0,001 \text {; } \\
\text { OR=1,45) beresiko } \\
\text { meningkatkan } \\
\text { kejadian stunting } \\
\text { pada anak usia 0-5 } \\
\text { tahun di Wilayah } \\
\text { pedesaan Indonesia }\end{array}$ \\
\hline 12 & $\begin{array}{l}\text { Torlesse et } \\
\text { al., } 2016\end{array}$ & $\begin{array}{l}\text { Determinants of } \\
\text { stunting in } \\
\text { Indonesian } \\
\text { children: evidence } \\
\text { from a cross- } \\
\text { sectional survey } \\
\text { indicate a } \\
\text { prominent role for } \\
\text { the water, sanitation }\end{array}$ & $\begin{array}{l}\text { VI: } \\
\text { - Sanitasi } \\
\text { penggunaan } \\
\text { fasilitas jamban } \\
\text { - Pembuangan } \\
\text { tinja balita } \\
\text { - Cuci tangan } \\
\text { pakai sabun } \\
\text { - Sumber air }\end{array}$ & $\begin{array}{l}\text { Cross- } \\
\text { Sectional }\end{array}$ & $\begin{array}{l}1.366 \\
\text { anak } \\
\text { usia } 0- \\
35 \\
\text { bulan }\end{array}$ & $\begin{array}{l}\text { Mengkonsumsi air } \\
\text { yang diolah beresiko } \\
(\mathrm{AOR}=3,47,95 \% \mathrm{CI} \\
1,73-7,28, \mathrm{P}<0,001) \\
\text { meningkatkan } \\
\text { kejadian stunting } \\
\text { pada anak } \\
\text { dibandingkan } \\
\text { penggunaan jamban }\end{array}$ \\
\hline
\end{tabular}


DOI: $10.31004 /$ obsesi.v5i2.788

\begin{tabular}{|c|c|c|c|c|c|c|}
\hline No & $\begin{array}{l}\text { Penulis / } \\
\text { Tahun }\end{array}$ & Judul Penelitian & $\begin{array}{l}\text { Variabel } \\
\text { Penelitian } \\
\text { (VI dan VD) }\end{array}$ & $\begin{array}{l}\text { Desain } \\
\text { Penelitian }\end{array}$ & Sampel & Hasil \\
\hline & & $\begin{array}{l}\text { and hygiene sector } \\
\text { in stunting } \\
\text { reduction }\end{array}$ & $\begin{array}{l}\text { - Pengolahan air } \\
\text { VD: Stunting dan } \\
\text { stunting } \\
\text { berat }\end{array}$ & & & $\begin{array}{l}\text { unimproved. Sanitasi } \\
\text { penggunaaan fasilitas } \\
\text { jamban unimproved } \\
(\mathrm{p}=0,001) \text {, } \\
\text { pembuangan tinja } \\
\text { balita }(\mathrm{p}=0,008) \text {, } \\
\text { pengolahan air } \\
\text { minum ( } \mathrm{p}=0,011) \\
\text { berhubungan dengan } \\
\text { kejadian stunting } \\
\text { berat pada anak usia } \\
\text { 0-35 bulan di wilayah } \\
\text { kabupaten Sikka, } \\
\text { Jayawijaya dan } \\
\text { Klaten Indonesia. }\end{array}$ \\
\hline 13 & $\begin{array}{l}\text { Wiyono et } \\
\text { al., } 2019\end{array}$ & $\begin{array}{l}\text { The Role Sanitation } \\
\text { To Stunting } \\
\text { Children Age 6-35 } \\
\text { Months, Purwojati } \\
\text { Subdistrict, } \\
\text { Banyumas District, } \\
\text { Central Java, } \\
\text { Indonesia }\end{array}$ & $\begin{array}{l}\text { VI: } \\
\text { - Kebersihan } \\
\text { jamban } \\
\text { - Sumber air } \\
\text { minum } \\
\text { VD: Stunting }\end{array}$ & $\begin{array}{l}\text { Cross- } \\
\text { Sectional }\end{array}$ & $\begin{array}{l}348 \\
\text { anak } \\
\text { usia } 6- \\
35 \\
\text { bulan }\end{array}$ & $\begin{array}{l}\text { Kebersihan jamban } \\
(\mathrm{p}=0,032) \\
\text { berhubungan dengan } \\
\text { kejadian stunting } \\
\text { pada balita yang } \\
\text { tinggal di pedesaan } \\
\text { Kec.Purvojati- Kab. } \\
\text { Banyumas. }\end{array}$ \\
\hline 14 & $\begin{array}{l}\text { Cahyono et } \\
\text { al, } 2016\end{array}$ & $\begin{array}{l}\text { Faktor Penentu } \\
\text { Stunting Anak } \\
\text { Balita Pada } \\
\text { Berbagai Zona } \\
\text { Ekosistem Di } \\
\text { Kabupaten Kupang }\end{array}$ & $\begin{array}{l}\text { VI: } \\
\text { - Sanitasi } \\
\text { lingkungan } \\
\text { VD: Stunting }\end{array}$ & $\begin{array}{l}\text { Case } \\
\text { Control }\end{array}$ & $\begin{array}{l}132 \text { anak } \\
\text { usia } 12- \\
59 \text { bulan } \\
\text { dibagi: } \\
66 \text { kasus, } \\
66 \\
\text { kontrol }\end{array}$ & $\begin{array}{l}\text { Sanitasi lingkungan } \\
\text { tidak layak ( } \mathrm{p}=0,034, \\
\text { OR=3,978) } \\
\text { berhubungan dengan } \\
\text { peningkatan kejadian } \\
\text { stunting pada anak } \\
\text { yang tinggal di zona } \\
\text { ekosistem } \\
\text { pegunungan } \\
\text { dibandingkan dengan } \\
\text { faktor sanitasi } \\
\text { lingkungan yang } \\
\text { kurang } \\
\text { ( } \mathrm{p}=0,046 ; O R=2,832) \\
\text { pada anak yang } \\
\text { tinggal di zona } \\
\text { dataran sedang } \\
\text { Kabupaten Kupang }\end{array}$ \\
\hline 15 & $\begin{array}{l}\text { Hafid et al, } \\
2017\end{array}$ & $\begin{array}{l}\text { Efek Program } \\
\text { SBABS Terhadap } \\
\text { Pencegahan } \\
\text { Stunting Anak } \\
\text { Baduta di } \\
\text { Kabupaten Banggai } \\
\text { dan Sigi }\end{array}$ & $\begin{array}{l}\text { VI: } \\
\text { - Perilaku Buang } \\
\text { Air Besar } \\
\text { - Sumber air } \\
\text { minum } \\
\text { VD: Stunting }\end{array}$ & Cohort & $\begin{array}{l}352 \\
\text { anak } \\
\text { usia 6- } \\
23 \text { bulan }\end{array}$ & $\begin{array}{l}\text { Perilaku perilaku } \\
\text { buang besar } \\
\text { sembarangan ( } \mathrm{p} \\
\text { value }=0,021 \text { ), secara } \\
\text { signifikan } \\
\text { berhubungan dengan } \\
\text { stunting pada anak } \\
\text { baduta di Kabupaten } \\
\text { Banggai dan Sigi. }\end{array}$ \\
\hline 16 & $\begin{array}{l}\text { Hasan \& } \\
\text { Kadarusman } \\
, 2019\end{array}$ & $\begin{array}{l}\text { Akses ke Sarana } \\
\text { Sanitasi Dasar } \\
\text { sebagai Faktor } \\
\text { Risiko }\end{array}$ & $\begin{array}{l}\text { VI: } \\
-\quad \text { Pemanfaatan } \\
\text { jamban Sehat }\end{array}$ & $\begin{array}{l}\text { Case } \\
\text { Control }\end{array}$ & $\begin{array}{l}400 \text { anak } \\
\text { usia } 6-59 \\
\text { bulan }\end{array}$ & $\begin{array}{l}\text { Pemanfaatan jamban } \\
\text { sehat }(\mathrm{OR}=5,25) \text {, } \\
\text { pemanfaatans umber } \\
\text { air bersih }(\mathrm{OR}=5,99) \\
\text { beresiko }\end{array}$ \\
\hline
\end{tabular}




\begin{tabular}{|c|c|c|c|c|c|c|}
\hline No & $\begin{array}{l}\text { Penulis / } \\
\text { Tahun }\end{array}$ & Judul Penelitian & $\begin{array}{l}\text { Variabel } \\
\text { Penelitian } \\
\text { (VI dan VD) }\end{array}$ & $\begin{array}{l}\text { Desain } \\
\text { Penelitian }\end{array}$ & Sampel & Hasil \\
\hline & & $\begin{array}{l}\text { Kejadian Stunting } \\
\text { pada Balita Usia 6- } \\
59 \text { Bulan }\end{array}$ & $\begin{array}{l}\text { Pemanfaatan } \\
\text { sumber air } \\
\text { bersih } \\
\text { VD: Stunting }\end{array}$ & & & $\begin{array}{l}\text { meningkatkan } \\
\text { kejadian stunting } \\
\text { pada anak usia balita } \\
\text { di } 9 \text { desa lokus } \\
\text { stunting di } \\
\text { Kabupaten Lampung } \\
\text { Timur. }\end{array}$ \\
\hline 17 & $\begin{array}{l}\text { Herawati et } \\
\text { al., } 2020\end{array}$ & $\begin{array}{l}\text { Hubungan Sarana } \\
\text { Sanitasi, Perilaku } \\
\text { Penghuni, dan } \\
\text { Kebiasaan Cuci } \\
\text { Tangan Pakai } \\
\text { Sabun (CTPS) oleh } \\
\text { Ibu dengan } \\
\text { Kejadian Pendek } \\
\text { (Stunting) pada } \\
\text { Balita Usia 6-24 } \\
\text { Bulan di Wilayah } \\
\text { Kerja Puskesmas } \\
\text { Harapan Baru, } \\
\text { Samarinda }\end{array}$ & $\begin{array}{ll}\text { VI: } \\
\text { - } & \text { Kualitas } \\
& \text { Sarana } \\
& \text { Sanitasi } \\
\text { - } & \text { Kualitas } \\
& \text { Perilaku } \\
& \text { Penghuni } \\
\text { - } & \text { Kualitas CTPS } \\
& \text { Ibu } \\
& \\
\text { VD: Stunting }\end{array}$ & $\begin{array}{l}\text { Case } \\
\text { Control }\end{array}$ & $\begin{array}{l}38 \text { ibu } \\
\text { yang } \\
\text { memiliki } \\
\text { anak } \\
\text { usia 6-24 } \\
\text { bulan }\end{array}$ & $\begin{array}{l}\text { Kualitas sarana } \\
\text { sanitasi kepemilikan } \\
\text { jamban }(\mathrm{p}=0,000 ; \\
\text { OR=31,875), } \\
\text { perilaku penghuni } \\
\text { kebiasaan membuang } \\
\text { tinja balita } \\
\text { sembarangan }(\mathrm{p}= \\
\text { 0,000; OR = 18,417) } \\
\text { berhubungan dengan } \\
\text { peningkatan stunting } \\
\text { pada balita di } \\
\text { Wilayah Kerja } \\
\text { Puskesmas Harapan } \\
\text { Baru, Samarinda. }\end{array}$ \\
\hline 18 & $\begin{array}{l}\text { Lobo et al., } \\
2020\end{array}$ & $\begin{array}{l}\text { Faktor Penentu } \\
\text { Kejadian Stunting } \\
\text { Pada Anak Balita Di } \\
\text { Wilayah Kerja } \\
\text { Puskesmas Alak } \\
\text { Kota Kupang }\end{array}$ & $\begin{array}{l}\text { VI: Praktik } \\
\text { Kebersihan } \\
\text { dan Sanitasi } \\
\text { Lingkungan } \\
\text { VD: Stunting }\end{array}$ & $\begin{array}{l}\text { Case } \\
\text { Control }\end{array}$ & $\begin{array}{l}110 \text { anak } \\
\text { balita: } 55 \\
\text { kasus } \\
\text { dan } 55 \\
\text { kontrol }\end{array}$ & $\begin{array}{l}\text { Praktik kebersihan } \\
\text { dan sanitasi } \\
\text { lingkungan yang } \\
\text { kurang baik ( } \mathrm{p}=0,000 ; \\
\text { OR=7,986) } \\
\text { berhubungan dengan } \\
\text { peningkatan kejadian } \\
\text { stunting pada anak } \\
\text { balita di wilayah } \\
\text { puskesmas Alak Kota } \\
\text { Kupang. }\end{array}$ \\
\hline 19 & Nasrul, 2018 & $\begin{array}{l}\text { Pengendalian } \\
\text { Faktor Risiko } \\
\text { Stunting Anak } \\
\text { Baduta Di Sulawesi } \\
\text { Tengah }\end{array}$ & $\begin{array}{l}\text { VI: } \\
\text { - Sumber air } \\
\text { - Kepemilikan } \\
\text { jamban } \\
\text { VD: Stunting }\end{array}$ & $\begin{array}{l}\text { Cross } \\
\text { Sectional }\end{array}$ & $\begin{array}{l}384 \text { anak } \\
\text { baduta }\end{array}$ & $\begin{array}{l}\text { Tidak memiliki } \\
\text { jamban ( } \mathrm{p}=0,00 ; \mathrm{OR}= \\
7,398) \text {, sumber air } \\
\text { tidak terlindungi } \\
(\mathrm{p}=0,000) \\
\text { berhubungan dengan } \\
\text { peningkatan kejadian } \\
\text { stunting pada anak } \\
\text { baduta di Sulawesi } \\
\text { Tengah. }\end{array}$ \\
\hline 20 & $\begin{array}{l}\text { Rahayu \& } \\
\text { Darmawan, } \\
2019\end{array}$ & $\begin{array}{l}\text { Hubungan } \\
\text { Karakteristik Balita, } \\
\text { Orang Tua, Higiene } \\
\text { Dan Sanitasi } \\
\text { Lingkungan } \\
\text { Terhadap Stunting } \\
\text { Pada Balita }\end{array}$ & $\begin{array}{l}\text { VI: } \\
\text { - Sanitasi } \\
\text { lingkungan } \\
\text { VD: Stunting }\end{array}$ & $\begin{array}{l}\text { Cross } \\
\text { Sectional }\end{array}$ & 76 balita & $\begin{array}{l}\text { Sanitasi lingkungan } \\
\text { ( } \mathrm{p} \text { value }=0,000 \text { ) } \\
\text { memiliki hubungan } \\
\text { yang signifikan } \\
\text { dengan kejadian } \\
\text { stunting pada balita } \\
\text { dikelurahan } \\
\text { kampung melayu. }\end{array}$ \\
\hline 21 & $\begin{array}{l}\text { Zairinayati } \\
\text { \& Purnama, } \\
2019\end{array}$ & $\begin{array}{l}\text { Hubungan Hygiene } \\
\text { Dan Sanitasi } \\
\text { Lingkungan }\end{array}$ & $\begin{array}{l}\text { VI: } \\
\text { - Kepemilikan } \\
\text { Jenis Jamban }\end{array}$ & $\begin{array}{l}\text { Case } \\
\text { Control }\end{array}$ & $\begin{array}{l}60 \\
\text { orang } \\
\text { balita: } \\
30\end{array}$ & $\begin{array}{l}\text { Jenis jamban }(p= \\
0,000 ; O R=2,86), \\
\text { sumber air bersih } \\
(p=0,001 ; O R=0,130) \text {, }\end{array}$ \\
\hline
\end{tabular}




\begin{tabular}{|c|c|c|c|c|c|c|}
\hline No & $\begin{array}{l}\text { Penulis / } \\
\text { Tahun }\end{array}$ & Judul Penelitian & $\begin{array}{l}\text { Variabel } \\
\text { Penelitian } \\
\text { (VI dan VD) }\end{array}$ & $\begin{array}{l}\text { Desain } \\
\text { Penelitian }\end{array}$ & Sampel & Hasil \\
\hline & & $\begin{array}{l}\text { Dengan Kejadian } \\
\text { Stunting Pada Balita }\end{array}$ & $\begin{array}{l}\text { - Sumber Air } \\
\text { Bersih } \\
\text { VD: Stunting }\end{array}$ & & $\begin{array}{l}\text { kasus } \\
\text { dan } 30 \\
\text { kontrol }\end{array}$ & $\begin{array}{l}\text { berhubungan dengan } \\
\text { peningkatan kejadian } \\
\text { stunting pada balita } \\
\text { di wilayah kerja } \\
\text { Puskesmas Maryana } \\
\text { Kec. Banyuasin I Kab. } \\
\text { Banyuasin. }\end{array}$ \\
\hline
\end{tabular}

Hasil systematic review menemukan bahwa sebagian besar hasil penelitian mengungkapkan faktor air dan sanitasi berhubungkan dengan peningkatan kejadian stunting pada balita di Indonesia. Hal ini sesuai dengan kerangka konsep UNICEF 2013, Fenske et al, 2013 dan WHO, 2014.

\section{Faktor Air Dengan Kejadian Stunting Pada Balita di Indonesia}

Sebagian besar bukti hasil penelitian di Indonesia menunjukkan bahwa faktor air mencakup sumber air minum unimproved, pengolahan air minum dapat meningkatkan kejadian stunting pada balita (Badriyah \& Syafiq, 2017; Fikru \& Doorslaer, 2019; Hasanah \& Susanti., 2018; Irianti S, et al., 2019; Otsuka et al., 2019; Rahayu et al., 2018; Siswati, 2019; Torlesse. et al, 2016; Hasan \& Kadarusman., 2018; Nasrul, 2018; Zairinayati \& Purnama, 2019). Sebagian besar balita stunting tinggal di wilayah pedesaan yang mengalami kesulitan dalam mengakses sumber air minum yang aman.

Hasil penelitian Otsuka et al, (2018), mengungkapkan bahwa rumah tangga yang mengkonsumsi air minum bersumber dari air ledeng dapat meningkatkan kejadian stunting pada anak dibandingkan dengan rumah tangga yang menggunakan air tangki dan sumur. Hal ini dapat terjadi apabila kualitas air ledeng yang digunakan oleh rumah tangga, tidak memenuhi syarat kualitas fisik dibandingkan dengan air tangki dan sumur. Berdasarkan permenkes RI No. 32/2017, kualitas fisik air minum harus memenuhi syarat kesehatan yaitu tidak keruh/ jernih, tidak memiliki rasa, tidak berbau, tidak kontaminasi dengan zat kimia serta bebas dari berbagai mikroorganisme yang dapat menyebabkan anak mengalami stunting.

Beberapa bukti temuan di Indonesia, memiliki kesamaan dengan hasil temuan dari luar negeri yang mengungkapkan bahwa air (water) unimproved meningkatkan kejadian stunting pada balita. Temuan di Ethiopia mengungkapkan bahwa sumber air minum berhubungan dengan kejadian stunting pada anak balita (Kwami., et al, 2019). Penelitian Batiro et al, (2017) di Ethiopio mengungkapkan bahwa mengkonsumsi air dari sumber unimproved, beresiko tujuh kali meningkatkan kejadian stunting pada anak. Penelitian lain mengatakan sumber air minum yang tidak aman, jarak sumber air dari tempat pembuangan, kuantitas, kualitas, penyimpanan, pengolahan dan keterjangkan air berhubungan dengan kejadian stunting pada balita (Cumming \& Cairncross, 2016; Dodos et al, 2017).

Ketersediaan air minum yang unimproved berasal dari sumber unimproved, jarak sumber air terlalu dekat dengan jamban, pengolahan air yang tidak sesuai sebelum dikonsumsi dapat menyebabkan gangguan gizi pada anak-anak. Hal ini terjadi karena air mengandung mikroorganisme patogen dan bahan kimia lainnya, menyebabkan anak mengalami penyakit diare dan EED (Aguayo \& Menon, 2016). Jika diare berlanjut melebihi dua minggu mengakibatan anak mengalami gangguan gizi berupa stunting (Akombi et al., 2017). Oleh karena itu dibutuhkan perhatian dari semua pihak terutama keluarga terhadap kebutuhan air minum yang aman di mulai dari sumber air terlindungi, kuantitas, kualitas, penyimpanan dan pengolahan air terutama pada 1000 HPK untuk mencegah dan mengurangi kejadian stunting pada balita di Indonesia. 


\section{Faktor Sanitasi Dengan Kejadian Stunting Pada Balita di Indonesia}

Sebagian besar hasil temuan di wilayah Pedesaan Indonesia terkait sanitasi penggunaan fasilitas jamban mulai dari kepemilikan jamban, jenis jamban, jamban tidak menggunakan septik tangki, kebersihan jamban, perilaku Open defecation dan pembuangan tinja balita tidak pada jamban berhubungan dengan peningkatan stunting pada balita di Indonesia (Ahmadi et al., 2020; Badriyah \& Syafiq, 2017; Choirunnisa et al., 2020; Dwipayanti et al., 2020; Fikru \& Doorslaer, 2019; Hasanah \& Susanti., 2018; ; Hafid., et al, 2017; Hasan \& Kadarusman., 2018; Herawati et al., 2020; Nasrul, 2018; Otsuka et al., 2019; Rahayu et al., 2017; Rahayu et al., 2018; Lobo et al, 2020; Siswati, 2018; Torlesse. et al, 2016; Wiyono et al., 2019; cahyono et al., 2016; Rahayu dan Darmawan, 2019; Zairinayati \& Purnama, 2019) .

Hasil temuan ini sejalan dengan penelitian Fregonese et al., (2016), menyatakan bahwa anak yang hidup di lingkungan terkontaminasi dengan sanitasi yang tidak layak memiliki resiko $40 \%$ mengalami stunting dan secara signifikan lebih tinggi dipedesaan dan pinggiran kota $(43 \%$ vs $27 \%)$ dibandingkan dengan yang tinggal di perkotaan $(5 \%)$. Sebuah analisis di India membuktikan bahwa tingkat kejadian stunting tertinggi pada anak-anak yang tinggal dipedesaan dikarenakan sebagian besar masyarakat masih melakukan open defecation (Chakravarty et al, 2017).

Analisis serupa dilakukan oleh Bagcchi (2015), mengungkapkan bahwa praktek buang air besar ditempat terbuka berhubungan dengan kejadian stunting pada anak balita di India. Perilaku tersebut menyebabkan pencemaran lingkungan akibat penyebaran kuman patogen dari fecal. Apabila kuman tersebut tersentuh oleh anak yang dalam proses pertumbuhan yang memiliki perilaku memasukkan jari kedalam mulut menyebabkan anak akan menelan sejumlah bakteri fekal yang dapat menginfeksi usus. Kondisi infeksi usus berupa diare dan EED dapat mempengaruhi status gizi anak dengan mengurangi nafsu makan, mengganggu penyerapan gizi yang menyebabkan anak mengalami kekurangan gizi dan gangguan pertumbuhan (Owino et al.,2016).

Penggunaan fasilitas jamban yang tidak memenuhi syarat kesehatan, praktek open defecation dan pembuangan feces balita tidak pada jamban menyebabkan anak-anak terkontaminasi dengan pencemaran lingkungan, sehingga memudahkan penularan patogen yang berasal dari tinja dan meningkatkan kejadian stunting pada balita. Studi yang dilakukan di Peru membuktikan bahwa pembuangan tinja balita yang tidak aman, penggunaan jamban oleh anak-anak yang rendah akibat resiko tinggi jatuh pada anak, meningkatkan prevalensi diare, penyakit cacingan dan kejadian stunting pada balita (Brown et al., 2013). Oleh karena itu dibutuhkan perhatian khusus dari keluarga dalam pembuangan tinja balita harus pada toilet yang sesuai.

Penelitian Fikru dan Doorslaer, (2019), di 13 provinsi Indonesia menemukan bahwa rumah tangga yang memiliki sanitasi yang baik berkontribusi positif dalam mengurangi angka kejadian stunting dan stunting berat pada anak balita di Indonesia di tahun 2007-2014. Temuan tersebut senada dengan temuan Rah., et al (2015), yang menjelaskan bahwa akses keluarga terhadap fasilitas toilet yang memadai dapat mengurangi kejadian stunting pada anak usia 0-23 bulan mencapai 16-39\%. Dodos et al., (2017), menjelaskan bahwa sanitasi menjadi perhatian dalam penanganan stunting pada anak di mulai dari pembangunan konstruksi jamban yang memenuhi syarat kesehatan, mengurangi kebiasaan buang air besar sembarangan yang dilakukan oleh individu, pembuangan tinja balita pada jamban dan memperhatikan kebersihan lingkungan dengan tetap memperhatikan intervensi gizi spesifik.

Upaya mengurangi kejadian stunting pada balita di Indonesia dibutuhkan intervensi gizi sensitif dengan perbaikan sanitasi lingkungan, pembangunan konstruksi jamban yang memenuhi syarat kesehatan, melakukan upaya promotif kesehatan dengan edukasi untuk meningkatkan kesadaran masyarakat agar tidak melakukan perilaku open defecation dan pembuangan tinja termasuk tinja balita harus pada jamban. Tindakan tersebut bertujuan 
untuk mencegah fecal transmition sebagai vektor pembawa penyakit pada manusia dan lingkungan sekitarnya. Dengan demikian dapat memutuskan mata rantai penyebaran penyakit seperti diare, EED, cacingan mengurangi kejadian stunting pada balita di Indonesia

\section{SIMPULAN}

Berbagai faktor dihubungkan dengan kejadian stunting pada balita dan saling berhubungan satu sama lain. Berdasarkan hasil dan pembahasan dari systematic review ini ditemukan bukti bahwa faktor air dan sanitasi yang tidak layak mencakup sumber air minum unimproved, pengolahan air yang tidak sesuai, sanitasi penggunaan fasilitas jamban, kepemilikan jamban, perilaku open defecation, dan pembuangan tinja balita tidak pada jamban berhubungan dengan peningkatan kejadian stunting pada balita di Indonesia. Perlu adanya peningkatan upaya promosi kesehatan dan pengawasan program WASH dalam intervensi gizi sensitif, terutama di wilayah pedesaan Indonesia pada 1000 hari pertama kehidupan untuk mencegah kejadian stunting pada balita di Indonesia.

\section{UCAPAN TERIMA KASIH}

Kami mengucapkan terima kasih kepada Henny Suzana Mediani, S.Kp., MNg., Ph.D dan Windy Rakhmawati, S.Kp., M.Kep, Ph.D, atas kontribusinya dalam penulisan artikel ini. Artikel ini merupakan bagian dari thesis penulis yang berjudul Hubungan Air, Sanitasi Dan Higiene Dengan Kejadian Stunting Pada Balita Di Indonesia: Systematic Review.

\section{DAFTAR PUSTAKA}

Aguayo, V. M., \& Menon, P. (2016). Introduction Stop Stunting : Improving Child Feeding, Women's Nutrition And Household Sanitation In South Asia. 12, 3-11. https://doi.org/10.1111/mcn.12283

Akombi, B., Agho, K. E., Hall, J. J., \& Astell-burt, T. E. (2017). Stunting And Severe Stunting Among Children Under-5 Years In Nigeria : A Multilevel Analysis. 17.

Ahmadi, Sulistyorini, L., Azizah, R., \& Oktarizal, H. (2020). Association Between Toilet Availability and Handwashing Habits and the Incidence of Stunting in Young Children in Tanjung Pinang City , Indonesia. Malaysian Journal of Medicine and Health Sciences (EISSN 2636-9346), 16(May), 215-218.

Badriyah, L., Syafiq, A. (2017). The Association Between Sanitation , Hygiene, and Stunting in Children Under Two-Years. Makara Journal of Health Research, 21(2). https://doi.org/10.7454/msk.v21i2.6002

BAPPENAS \& UNICEF. (2017). Laporan Baseline SDG tentang Anak-Anak di Indonesia.

Bagcchi, S. (2015). India' s poor sanitation and hygiene practices are linked to stunting in children, study finds. 1564(March), 5180. https:// doi.org/10.1136/ bmj.h1564

Batiro, B., Demissie, T., Halala, Y., \& Anjulo, A. A. (2017). Determinants Of Stunting Among Children Aged 6-59 Months At Kindo Didaye Woreda, Wolaita Zone, Southern Ethiopia: Unmatched Case Control Study. PLoS ONE 12(12): e0189106. https://doi. org/10.1371/journal.pone.0189106.

Brown, J., Cairncross, S., \& Ensink, J. H. J. (2013). Water, Sanitation, Hygiene And Enteric Infections In Children. Archives of Disease in Childhood, 98(8), 629-634. https:// doi.org/10.1136/archdischild-2011-301528

Bukusuba, J., Kaaya, A. N., \& Atukwase, A. (2017). Predictors Of Stunting In Children Aged 6 To 59 Months: A Case-Control Study In Southwest Uganda. 38(4), 542-553. https://doi.org/10.1177/0379572117731666

Cahyono, F., Manongga, \& Picauly, I. (2016). Faktor Penentu Stunting Anak Balita Pada Berbagai Zona Ekosistem Di Kabupaten Kupang. J. Gizi Pangan, 11(1), 9-18.

Chakravarty, I., Bhattacharya, A., \& Das, S. K. (2017). Water, sanitation and hygiene: the 
unfinished agenda in the World Health Organization South-East Asia Region. WHO South-East Asia. Journal of Public Health. 22-26.

Choirunnisa, R., Indrayani, T., \& Anshor, F. L. (2020). Analysis Of Factors Related To Stunting In Toddlers Aged 25- 59 Months In Puspasari Village , Puspahiyang, Tasikmalaya 2019. STRADA Jurnal Ilmiah Kesehatan, 9(1), 177-182. https://doi.org/10.30994/sjik.v9i1.279.

Cumming, O., \& Cairncross, S. (2016). Review Article Can Water, Sanitation And Hygiene Help Eliminate Stunting ? Current Evidence And Policy Implications. 12, 91-105. https://doi.org/10.1111/mcn.12258

de Onis, M., \& Branca, F. (2016). Childhood Stunting : A Global Perspective. Maternal and Child Nutrition, 12, 12-26. https:/ / doi.org/10.1111/mcn.12231

Dodos, J., Mattern, B., Lapegue, J., Altmann, M., \& Aissa, M. A. I. T. (2017). Relationship Between Water, Sanitation, Hygiene, And Nutrition: What Do Link NCA Nutrition Causal Analyses Say? Journal Waterlines36(4).

Dwipayanti N. M. U., Sutiari, N.K., Dewiyani, C. I., M., \& H.K. (2020). Potential Association of Sanitation Factors on Stunting Incidences Among Children Under Age 5 in Bali Province, Indonesia. Advances in Health Sciences Research, 22(Ishr 2019), 24-28.

Fenske, N., Burns, J., Hothorn, T., \& Rehfuess, E. A. (2013). Understanding Child Stunting in India: A Comprehensive Analysis of Socio-Economic, Nutritional and Environmental Determinants Using Additive Quantile Regression. 8(11). https://doi.org/10.1371/journal.pone.0078692

Fikru, M., \& Doorslaer, E. Van. (2019). Population Health Explaining the fall of socioeconomic inequality in childhood stunting in Indonesia. SSM - Population Health, 9, 100469. https://doi.org/10.1016/j.ssmph.2019.100469

Fregonese, F., Siekmans, K., Kouanda, S., Druetz, T., Ly, A., Diabaté, S., \& Haddad, S. (2017). Impact Of Contaminated Household Environment On Stunting In Children Aged 12 - 59 Months In Burkina Faso. 356-363. https:/ / doi.org/10.1136/jech-2016-207423

Hafid, F., Djabu,U., Udin., Nasrul. (2018). Efek Program SBABS Terhadap Pencegahan Stunting Anak Baduta di Kabupaten Banggai dan Sigi. Indonesian Journal of Human Nutrition, 1(1), 14-22. https:/ / doi.org/10.21776/ub.ijhn.

Hasan, A., \& Kadarusman, H. (2019). Akses ke Sarana Sanitasi Dasar sebagai Faktor Risiko Kejadian Stunting pada Balita Usia 6-59 Bulan. Jurnal Kesehatan Volume 10, Nomor 3 http://ejurnal.poltekkes-tjk.ac.id/index.php/JK

Hasanah, I \& Susanti, H. (2018). Does water and sanitation effects on children's physical development? Evidence from Indonesia Family life Survey ( IFLS ) 2014. 09007(74). https://doi.org/https://doi.org/10.1051/e3sconf/20187409007

Headey, D., \& Palloni, G. (2019). Water, Sanitation , and Child Health : Evidence From Subnational Panel Data in 59 Countries. 729-752.

Herawati, Anwar, A., \& Setyowati, D. L. (2020). Hubungan Sarana Sanitasi , Perilaku Penghuni, dan Kebiasaan Cuci Tangan Pakai Sabun (CTPS) oleh Ibu dengan Kejadian Pendek ( Stunting ) pada Batita Usia 6-24 Bulan di Wilayah Kerja Puskesmas Harapan Baru , Samarinda. Jurnal Kesehatan Lingkungan Indonesia, 19(1), 7-15. https://doi.org/DOI : 10.14710/jkli.19.1.7-15.

Hossain, M., Choudhury, N., Adib, K., Abdullah, B., Mondal, P., Jackson, A. A., Walson, J., \& Ahmed, T. (2017). Evidence-Based Approaches To Childhood Stunting In Low And Middle Income Countries: A Systematic Review. https://doi.org/10.1136/archdischild

Irianti S, Prasetyoputra P, Dharmayanti I, Azhar K, H. P. S. (2019). The role of drinking water source, sanitation, and solid waste management in reducing childhood stunting in Indonesia. Earth and Environmental Science. https://doi.org/10.1088/1755$1315 / 344 / 1 / 012009$ 
Kementerian Kesehatan Republik Indonesia. (2018). Situasi Balita Pendek (Stunting) di Indonesia. Buletin Jendela Data Dan Informasi Kesehatan. ISSN 2088-270 X. www.depkes.go.id.

Kwami, C. S., Godfrey, S., Gavilan, H., Lakhanpaul, M., \& Parikh, P. (2019). Water, Sanitation , and Hygiene: Linkages with Stunting in Rural Ethiopia. Int. J. Environ. Res. Public Health, 16, 3793; doi:10.3390/ijerph16203793

Lobo, W. I., Talahatu, A. H., \& Riwu, R. R. (2020). Faktor Penentu Kejadian Stunting Pada Anak Balita Di Wilayah Kerja Puskesmas Alak Kota Kupang. Jurnal Media Kesehatan Masyarakat Https://Ejurnal.Undana.Ac.Id/MKM, 1(2), 59-67. https://doi.org/ISSN: 0852-6974.

Mbuya, M. N. N., \& Humphrey, J. H. (2016). Preventing Environmental Enteric Dysfunction Through Improved Water, Sanitation And Hygiene: An Opportunity For Stunting Reduction In Developing Countries. Maternal and Child Nutrition, 12, 106-120. https://doi.org/10.1111/mcn.12220

Nasrul. (2018). Pengendalian Faktor Risiko Stunting Anak Baduta Di Sulawesi Tengah. Promotif: Jurnal Kesehatan Masyarakat, 8(Desember), 131-146.

Otsuka, Y., Agestika, L., Sintawardani, N., \& Yamauchi, T. (2019). Risk Factors for Undernutrition and Diarrhea Prevalence in an Urban Slum in Indonesia : Focus on Water, Sanitation, and Hygiene. Am. J. Trop. Med. Hyg, 100(3), 727-732. https://doi.org/10.4269/ajtmh.18-0063

Owino, V., Ahmed, T., Freemark, M., \& Kelly, P. (2016). Environmental Enteric Dysfunction and Growth Failure / Stunting in Global Child Health. Pediatrics 138(6):e2016064. https://doi.org/10.1542/peds.2016-0641

Peraturan Menteri Kesehatan Republik Indonesia Nomor 32 Tahun 2017 Tentang Standar Baku Mutu Kesehatan Lingkungan Dan Persyaratan Kesehatan Air Untuk Keperluan Higiene Sanitasi, Kolam Renang, Solus Per Aqua, Dan Pemandian Umum.

Rabaoarisoa, C. R., Rakotoarison, R., Rakotonirainy, N. H., Mangahasimbola, R. T., Randrianarisoa, A. B., et al. (2017). The Importance Of Public Health, Poverty Reduction Programs And Women's Empowerment In The Reduction Of Child Stunting In Rural Areas Of Moramanga And Morondava, Madagascar. PLoS ONE, 12(10), 1-19. https:// doi.org/10.1371/journal.pone.0186493

Rah, J. H., Cronin, A. A., Badgaiyan, B., Aguayo, V. M., Coates, S., \& Ahmed, S. (2015). Household Sanitation And Personal Hygiene Practices Are Associated With Child Stunting In Rural India: A Cross-Sectional Analysis Of Surveys. https://doi.org/10.1136/bmjopen-2014-005180

Rahayu, B., \& Darmawan, S. (2019). Hubungan Karakteristik Balita, Orang Tua, Higiene dan Sanitasi Lingkungan terhadap Stunting pada Balita. Binawan Journal, 22-27. http://journal.binawan.ac.id/index.php/bsj/article/view/46/47

Rahayu, R. M., Pamungkasari, E. P., \& Wekadigunawan, C. S. P. (2018). The Biopsychosocial Determinants of Stunting and Wasting in Children Aged 12-48 Months. Journal of Maternal and Child Health, 2, 105-118. https:// doi.org/10.26911/thejmch.2018.03.02.03

Rahayu, R. M., Pamungkasari, E. P., \& Wekadigunawan, C. S. P. (2018). The Biopsychosocial Determinants of Stunting and Wasting in Children Aged 12-48 Months. Journal of Maternal and Child Health, 2, 105-118. https:// doi.org/10.26911/thejmch.2018.03.02.03

Riset Kesehatan Dasar. (2018). Laporan Nasional Riset Kesehatan Dasar 2018. Kementerian Kesehatan Republik Indonesia: Badan Penelitian Dan Pengembangan Kesehatan.

Siswati, T. (2018). Risk Factors for Stunting and Severe Stunting among under Five Years Children in Rural Areas in Indonesia. International Journal of Science and Research ISSN: 2319-7064, 8(11), 5-9.

Torlesse, H., Cronin, A. A., Sebayang, S. K., \& Nandy, R. (2016). Determinants Of Stunting In Indonesian Children: Evidence From A Cross-Sectional Survey Indicate A Prominent 
Role For The Water, Sanitation And Hygiene Sector In Stunting Reduction. BMC Public Health, 16(1), 1-12. https:/ / doi.org/10.1186/s12889-016-3339-8

Trihono., Atmarita., Tjandrarini, D.H., Irawati, A., Utami, N.H Tejayanti, T. Nurlinawati, L (2015). Pendek (Stunting ) di Indonesia, Masalah dan Solusinya. Jakarta : Badan Penelitian dan Pengembangan Kesehatan.

Vilcins, D., Sly, P. D., \& Jagals, P. (2018). Environmental Risk Factors Associated With Child Stunting : A Systematic Review Of The Literature. Annals of Global Health, 84(4),551562. https://doi.org/10.29024/aogh.2361

Vonaesch, P., Randremanana, R., Gody, J. C., Collard, J. M., Giles-Vernick, T., Doria, M., Vigan-Womas, I., Rubbo, P. A., Etienne, A., Andriatahirintsoa, E. J., Kapel, N., Brown, E., Huus, K. E., Duffy, D., Finlay, B. B., Hasan, M., Hunald, F. A., Robinson, A., Manirakiza, A., Gouandjika-Vassilache, I. (2018). Identifying the etiology and pathophysiology underlying Stunting and environmental enteropathy: Study protocol of the AFRIBIOTA project. BMC Pediatrics, 18(1), 1-19. https://doi.org/10.1186/s12887-018-1189-5.

World Health Organization. (2014). WHA global nutrition targets 2025: Stunting policy brief. Geneva: World Health Organization.

World Health Organization. (2018). Reducing Stunting In Children. Equity considerations for achieving the Global Nutrition Targets 2025. 5. Geneva World Health Organization.

Zairinayati, \& Purnama, R. (2019). Hubungan Hygiene Sanitasi dan Lingkungan dengan Kejadian Stunting Pada Balita. Jurnal Ilmiah Multi Science Kesehatan Vol. 10, 79. 